\title{
Numerical simulation of the effect of construction dust emission on air quality in Jinan, a Central City in the North China Plain
}

\author{
Guo J'., Wang Z.S. ${ }^{2, *}$ and Wang H.Y. ${ }^{1}$ \\ 1 Jinan Environmental Research Institute, Jinan 250101, China \\ ${ }^{2}$ State Key Laboratory of Environmental Criteria and Risk Assessment, Chinese Research Academy of Environmental Sciences, Beijing \\ 100012, China
}

Received: 06/03/2021, Accepted: 25/04/2021, Available online: 07/01/2022

*to whom all correspondence should be addressed: e-mail: 18701650609@163.com https://doi.org/10.30955/gnj.003588

\section{Graphical abstract}

2017

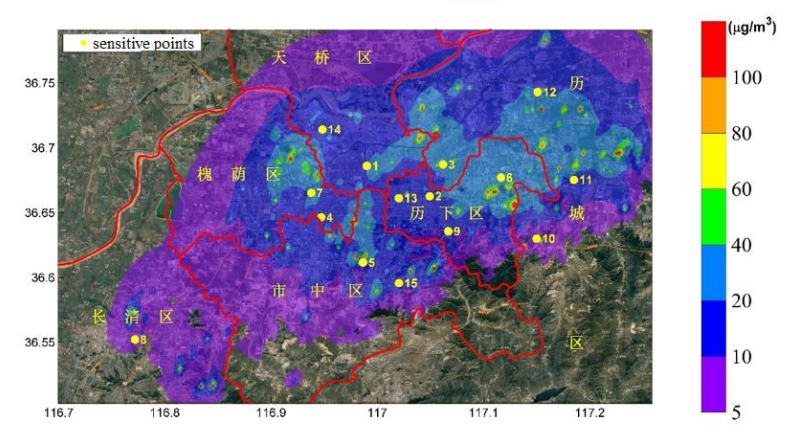

Abstract

Numerical simulation was conducted to assess the impact of dust emission on typical environmental sites in Jinan City. The CALPUFF model was applied to five simulation scenarios. The results showed that dust emission had a significant impact on air quality in Jinan. The impact of dust emission on the average concentration of $\mathrm{PM}_{10}$ at 15 monitoring sites was $19.8 \mu \mathrm{g} / \mathrm{m}^{3}$, accounting for $14.9 \%$ of the annual total. The impact of dust emission on the average concentration of $\mathrm{PM}_{2.5}$ was $5.2 \mu \mathrm{g} / \mathrm{m}^{3}$, accounting for $8.1 \%$ of the annual total. Adoption of yellow warning measures in the emission reduction scenarios had insignificant environmental effects due to unfavorable meteorological conditions. Compared with the baseline scenario, the average concentrations of $\mathrm{PM}_{10}$ and $\mathrm{PM}_{2.5}$ decreased by $13.6 \%$ and $1.9 \%$, respectively. After adoption of orange and red warning measures, the impact of site dust emission on air quality at the monitoring site was reduced significantly. Significant environmental effects were achieved after all construction sites within a 2-km radius of the monitoring site were closed. Compared with the baseline scenario, the average concentrations of $\mathrm{PM}_{10}$ and $\mathrm{PM}_{2.5}$ were reduced by $45.5 \%$ and $42.3 \%$, respectively. The results showed that under adverse meteorological conditions, higher-level warning measures should be undertaken to reduce the impact of site emissions on environmental quality. Considering the economic and social effects of emission reduction, temporary construction stoppage within $2 \mathrm{~km}$ of the monitoring site is a feasible plan that is in accordance with the goals of comprehensive environmental management.

Keywords: Jinan, Construction dust, Air quality, CALPUFF, Numerical simulation.

\section{Introduction}

With rapid urbanization in China, dust pollution from urban construction has become one of the main factors affecting air quality. Prevention of urban construction dust is essential for prevention and control of air pollution in various locations. According to a source analysis conducted in the City of Jinan, regional transmission accounts for 20$32 \%$ of atmospheric particulate matter $\left(\mathrm{PM}_{2.5}\right)$, while emissions from local pollution sources contribute $68-80 \%$ of air pollution. Coal, dust, industrial activities, and motor vehicles are four major sources of air pollution, accounting for $27 \%, 24 \%, 18 \%$ and $15 \%$ of air pollution, respectively. Emissions from other sources such as restaurants, car repair shops, livestock and poultry farming, and building coatings account for approximately $16 \%$ of $\mathrm{PM}_{2.5}$. Dust is one of the main factors causing air pollution, and construction sites are a major source of urban dust (Chung et al., 2014; Hye et al., 2009; Junpen et al., 2013; Liang et al., 2018; Liu et al., 2019; Niu et al., 2010). Thus, effective control of dust pollution generated from urban construction sites is essential.

Numerical simulation is an effective tool for assessing the impacts of dust emission on air quality (Chang et al., 2020; Don et al., 2018; Kirthiga and Patel, 2018; Lai et al., 2017; Latinopoulos et al., 2012; Maity et al., 2017; Misra et al., 2014). Zhang et al. (2010) employed the CALPUFF model to simulate the impact of construction dust emission on environmental quality in the City of Guiyang. The results showed that construction dust accounted for nearly $12 \%$ of the annual average concentration of $\mathrm{PM}_{10}$ across the entire urban area, with monthly contributions of up to $40 \%$ to $\mathrm{PM}_{10}$ and annual contributions exceeding $25 \%$ in some areas. Driven by the intensity of construction and meteorological conditions, seasonal trends in the impact of 
construction dust emission on air quality are clear. Xue et al. (2017) used the WRF/CMAQ model to simulate the impact of construction dust emission on air quality in Beijing. Their results showed that construction dust emission in Beijing has increased in a regularly fluctuating pattern over the years. Although the area covered by construction sites has decreased in recent years, the amount of construction remains high, resulting in high particulate matter emissions. Temporally, construction dust emission is greatest during summer and autumn. Spatially, construction dust is concentrated mainly in urban expansion areas and suburbs, where it is associated with the extension of human activities and the gradual outward progression of urbanization. Dust from construction contributed up to $31.3 \mu \mathrm{g} \cdot \mathrm{m}^{-3} \mathrm{PM}_{10}$ and $9.6 \mu \mathrm{g} \cdot \mathrm{m}^{-3} \mathrm{PM}_{2.5}$ in the air of Beijing. Zhao et al. (2009) simulated the impact of dust emission from construction sites on $\mathrm{PM}_{10}$ concentrations in Tianjin using the ISC3 model. The results revealed that the average concentration of $\mathrm{PM}_{10}$ produced from construction sites was $20.3 \mu \mathrm{g} \cdot \mathrm{m}^{-3}$, accounting for $13.3 \%$ of the atmospheric $\mathrm{PM}_{10}$ concentration.

The aim of this study was to analyze typical construction sites in Jinan and use the CALPUFF model to simulate their environmental impacts. The results will provide a scientific basis for the prevention and control of air pollution in Jinan.

\section{Methods and study region}

\subsection{Methods}

The CALPUFF model was selected for use in this study. CALPUFF is a guideline model recommended by the United States Environmental Protection Agency. It is a multilayered, multi-species, non-steady-state LaGrangian Gaussian smoke puff dispersion model. The model tracks the movement of a discrete smoke puff after release, simulating its diffusion, transformation, and clearance along its path until the puff leaves the simulation area. Spatiotemporal variations in meteorological conditions are explicitly considered during analysis of smoke puff diffusion. An important characteristic of non-steady-state diffusion is that the smoke puff can alter its path as the wind direction changes. During movement, smoke puffs follow the spatiotemporal variations in surface characteristics such as surface roughness and soil moisture content. The guideline on air quality models from the United States Environmental Protection Agency states that the purpose of the CALPUFF model is to assess the impacts of spatiotemporal changes in meteorological conditions on transport and diffusion. CALPUFF is a relatively mature model with a long history of development, which has been tested and evaluated by many users. CALPUFF can simulate moderate scales from dozens of meters to hundreds of kilometers, as well as some non-steady-state conditions (such as calm wind, fumigation, recirculation, complex terrain, and coastal conditions). Its meteorological modules include land and water boundary layer models that use the predicted wind field or station data as the initial estimated field to analyze the initial estimated wind field from morphodynamics and overland flow parameters, and it is suitable for simulation of complex terrain.
The CALPUFF model system includes three main modules, CALMET, CALPUFF, and CALPOST, as well as pre-processing programs for geographic and meteorological data (Atabi et al., 2016; Shekarrizfard et al., 2017). Briefly, CALMET is a meteorological model that establishes three-dimensional gridded wind and temperature fields in the simulation area and simultaneously generates two-dimensional mixing height, surface characteristics, and diffusion characteristics. CALPUFF is a transport and diffusion model. The puff released from the emission source is transported via advection, and its diffusion and transformation processes along the transport path are simulated. The meteorological field with spatiotemporal variations generated by CALMET is used to steer CALPUFF. The main output files of CALPUFF include the concentration field and deposition flux. CALPOST is a post-processing module used to process these output files, generate time-series files, calculate the maximum concentration, and identify points exceeding a certain threshold concentration.

\subsection{Study region}

Jinan, the capital of Shandong Province, is a typical polluted city on the North China Plain, hosting the highest $\mathrm{SO}_{2}, \mathrm{NOx}$, and $\mathrm{PM}_{2.5}$ emissions in China (Zhang et al., 2009) (Figure 1). Jinan is bordered by Tai Mountain to the south and the Yellow River to the north, with greater topographic variations in the south than in the north. The altitude of the area ranges from $23 \mathrm{~m}$ to $975 \mathrm{~m}$ above sea level, with high contrast relief. Hilly areas and alluvial plains lie across the city from south to north (Yang et al., 2012). The city has experienced dramatic population and spatial growth during the last 50 years, as the population has increased from 3.19 million in 1952 to 8.83 million in 2018, and the developed area increased from $24.6 \mathrm{~km}^{2}$ in 1949 to over $500 \mathrm{~km}^{2}$ in 2018. The semi-humid continental monsoon climate is characterized by cold, dry winters and hot, wet summers. The average annual precipitation is $636 \mathrm{~mm}$, with $75 \%$ occurring during the wet season.

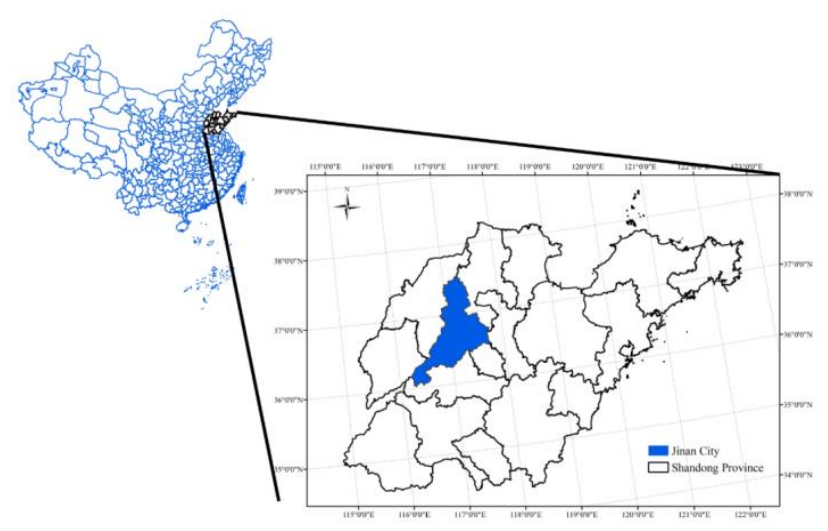

Figure 1. Location of the study area.

\section{Data sources}

\subsection{Geographic and meteorological data sources}

The use of CALMET to generate 3D diagnostic wind fields and $2 \mathrm{D}$ micrometeorological parameter fields requires the input of geographic data, including terrain height, land use, surface parameters (surface roughness, surface albedo, Bowen ratio, soil heat flux, and leaf area index) and anthropogenic heat flux. A common terrain database is 
provided in the CALMET user manual. This study used SRTM3 terrain elevation data with a resolution of $90 \mathrm{~m}$, provided by the United States Geological Survey, as the input for the terrain pre-processing module TERREL to obtain gridded terrain in the study area with a $100-\mathrm{m}$ resolution. Global land cover data from the United States Geological Survey, with a resolution of $1 \mathrm{~km}$, were used to assign land use and were input into the land-use preprocessing module CTGPROC. Due to the low resolution of global land-use data, in cases where the simulation mesh resolution was finer than the data resolution, the original land-use data with low resolution were divided into finer grids by increasing the sampling density of each grid. Gridded terrain and land-use data at the same resolution were input into the pre-processing module MAKEGEO, and the surface parameters of each grid were calculated using geographic parameters for various land-use types with the CALMET default settings to obtain geographic data (GEO.DAT) for the use of CALMET.

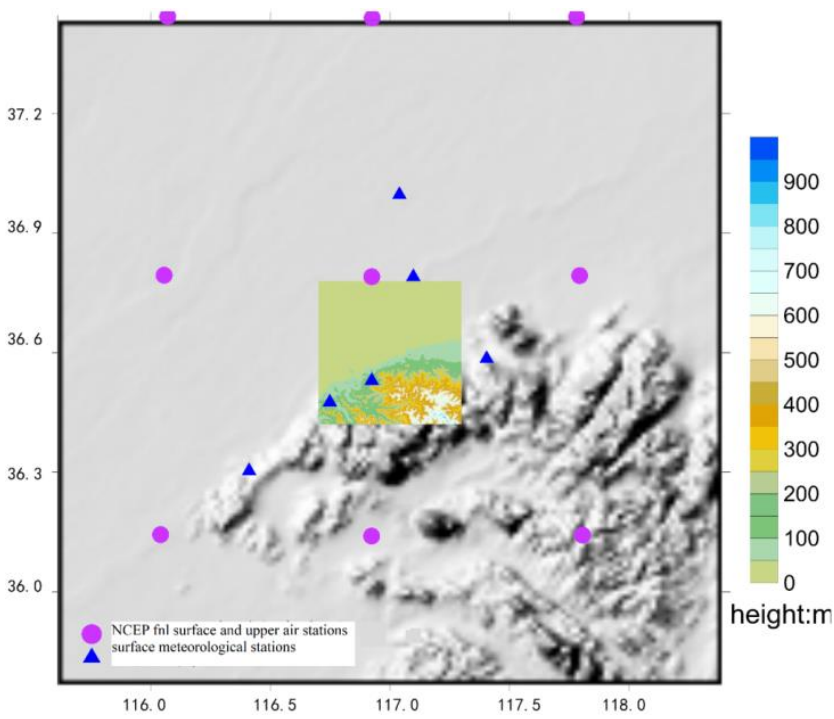

Figure 2. Locations of meteorological observation sites.

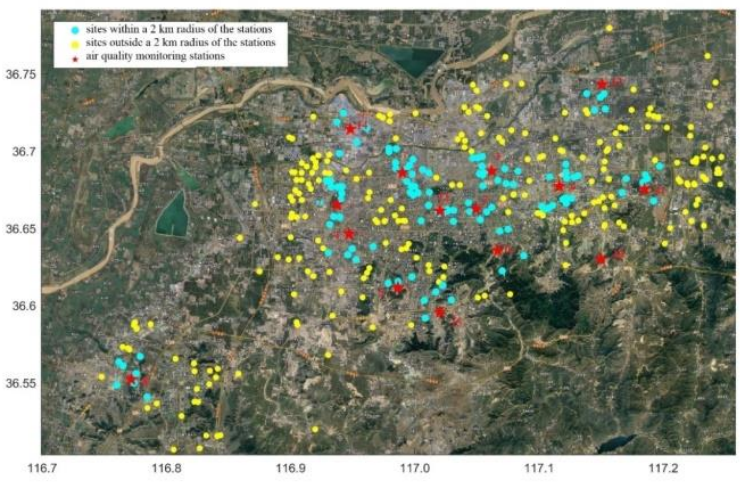

Figure 3. Locations of pollution sources and sensitive points.

Surface meteorological data include conventional surface meteorological observations from nine stations obtained from the meteorological element analysis field of the National Weather Service National Centers for Environmental Prediction (NCEP), including hourly wind direction, wind speed, temperature, relative humidity, precipitation, total cloud cover, and barometric pressure from six surface meteorological stations. Upper atmospheric data include sounding observations (pressure, altitude, temperature, wind direction, and wind speed in 13 layers from 1000 to $500 \mathrm{hPa}$ ) collected four times per day $(0000,0600,1200$, and 1800 UTC) at nine stations of the meteorological element analysis field of the National Weather Service National Centers for Environmental Prediction. Figure 2 shows the locations of the meteorological stations.

\subsection{Emission sources and sensitive points}

A total of 15 air quality monitoring stations in Jinan were selected as sensitive points (see Table 1 ). The simulation area includes these 15 points, and the boundary of the simulation area is $5 \mathrm{~km}$ from the nearest sensitive point. There were 724 construction sites within the simulation area. Simulations were performed for these sites, 220 of which were within a $2-\mathrm{km}$ radius of a sensitive point, as shown in Figure 3. The emissions from construction sites in 2017 and simulated emissions under five scenarios were provided by the Jinan Environmental Research Institute.

\section{Analysis of simulation results}

Five emission scenarios were analyzed in this study, as shown in Table 2. Emissions under scenarios with alerts issued were calculated based on the Emergency Plan for Heavy Air Pollution Weather in Jinan. The meteorological conditions were based on the 3 days from December 29 to December 31, 2017, when typical meteorological conditions unfavorable to diffusion occurred. Spatial distribution graphs of $\mathrm{PM}_{10}$ and $\mathrm{PM}_{2.5}$ were drawn for each scenario, and the concentrations at 15 sensitive points were extracted for analysis.

\subsection{Scenario 1 analysis}

Table 3 lists the concentrations of $\mathrm{PM}_{10}$ and $\mathrm{PM}_{2.5}$ at each sensitive point under this scenario and their contributions to the environmental concentration at the monitoring point. The monitoring values are annual average concentrations of particulate matter at each station. Figures 4 and 5 display the average concentration distributions of $\mathrm{PM}_{10}$ and $\mathrm{PM}_{2.5}$, respectively, under this scenario. The figures reveal that dust emission had the greatest impact on the average concentration of $\mathrm{PM}_{10}$ at sites located in the development zone, reaching 31.0 $\mu \mathrm{g} / \mathrm{m}^{3}$. The impact of dust emission on the average $\mathrm{PM}_{10}$ concentration across all 15 monitoring stations was 19.8 $\mu \mathrm{g} / \mathrm{m}^{3}$, accounting for $14.9 \%$ of the average monitoring value. Similarly, dust emission had the greatest impact on the average concentration of $\mathrm{PM}_{2.5}$ at stations within the development zone, reaching $7.8 \mu \mathrm{g} / \mathrm{m}^{3}$. Its impact on the average $\mathrm{PM}_{2.5}$ concentration at the 15 monitoring points was $5.2 \mathrm{\mu g} / \mathrm{m}^{3}$, accounting for $8.1 \%$ of the average monitoring values. The spatial distribution based on all construction sites in the simulation area showed the diffusion trajectories of $\mathrm{PM}_{2.5}$ and $\mathrm{PM}_{10}$ generally covering the entire simulation area, and areas with high concentrations were generally concentrated in the northern part of Lixia District and the western part of Licheng District. 
Table 1. Information about the 15 sensitive points

\begin{tabular}{cccc}
\hline No. & Name & Longitude & Latitude \\
\hline 1 & Jinan chemical plant & 116.9903 & 36.6861 \\
\hline 2 & Air quality monitoring station & 117.0494 & 36.6627 \\
\hline 3 & Seed warehouse & 117.0619 & 36.6872 \\
\hline 4 & Second machine tool plant & 116.9472 & 36.6464 \\
\hline 5 & Kegansuo site & 116.9866 & 36.6116 \\
\hline 6 & Development zone & 117.1164 & 36.6772 \\
\hline 7 & Nongkesuo site & 116.9378 & 36.6653 \\
\hline 8 & Changing Party School & 116.772 & 36.5522 \\
\hline 9 & School of Economics & 117.0669 & 36.6357 \\
\hline 10 & High and New School & 117.15 & 36.63 \\
\hline 11 & Construction College & 117.1851 & 36.6753 \\
\hline 12 & Jinan Baosheng site & 117.1509 & 36.7431 \\
\hline 13 & Quancheng Square & 117.0203 & 36.6612 \\
\hline 14 & Lanxiang Vocational School & 116.9483 & 36.7142 \\
\hline 15 & Shandong Luneng site & 117.0204 & 36.5957
\end{tabular}

Table 2. Simulation scenario descriptions

\begin{tabular}{cccc}
\hline No. & Scenario description & Pollution source emission & Meteorological conditions \\
\hline 1 & Basic scenario & Normal emissions from all construction sites & Year 2017 \\
\hline 2 & Yellow alert & Emissions reduced by 35\% & December 29-31, 2017 \\
\hline 3 & Orange alert & Emissions reduced by 70\% & December 29-31, 2017 \\
\hline 4 & Red alert & Emissions reduced by 90\% & December 29-31, 2017 \\
\hline 5 & Other emission reduction scenario & $\begin{array}{c}\text { Closing all construction sites within a 2-km radius } \\
\text { of meteorological stations }\end{array}$ & Year 2017 \\
\hline
\end{tabular}

Table 3. Concentrations of $\mathrm{PM}_{10}$ and $\mathrm{PM}_{2.5}$ under scenario 1 and their ratios to monitoring data

\begin{tabular}{|c|c|c|c|c|c|c|c|}
\hline \multirow[b]{2}{*}{ No. } & \multirow[b]{2}{*}{ Name } & \multicolumn{3}{|c|}{$\mathrm{PM}_{10}$ concentration $\left(\mu \mathrm{g} / \mathrm{m}^{3}\right)$} & \multicolumn{3}{|c|}{$\mathrm{PM}_{2.5}$ concentration $\left(\mu \mathrm{g} / \mathrm{m}^{3}\right)$} \\
\hline & & $\begin{array}{l}\text { Simulated } \\
\text { mean value }\end{array}$ & $\begin{array}{c}\text { Monitored } \\
\text { annual value }\end{array}$ & Ratio & $\begin{array}{l}\text { Simulated } \\
\text { mean value }\end{array}$ & $\begin{array}{c}\text { Monitored } \\
\text { annual value }\end{array}$ & Ratio \\
\hline 1 & Jinan chemical plant & 21.2 & 124 & $17.09 \%$ & 5.6 & 59 & $9.54 \%$ \\
\hline 2 & Air quality monitoring station & 17.4 & 132 & $13.19 \%$ & 4.8 & 70 & $6.91 \%$ \\
\hline 3 & Seed warehouse & 23.9 & 133 & $17.95 \%$ & 6.3 & 68 & $9.23 \%$ \\
\hline 4 & Second machine tool plant & 16.1 & 145 & $11.11 \%$ & 4.4 & 76 & $5.78 \%$ \\
\hline 5 & Kegansuo site & 24.7 & 121 & $20.40 \%$ & 6.3 & 59 & $10.74 \%$ \\
\hline 6 & Development zone & 31.0 & 116 & $26.74 \%$ & 7.8 & 58 & $13.42 \%$ \\
\hline 7 & Nongkesuo site & 22.8 & 148 & $15.42 \%$ & 5.8 & 62 & $9.42 \%$ \\
\hline 8 & Changing Party School & 7.4 & 122 & $6.08 \%$ & 2.0 & 64 & $3.16 \%$ \\
\hline 9 & School of Economics & 15.9 & 114 & $13.97 \%$ & 4.4 & 60 & $7.36 \%$ \\
\hline 10 & High and New School & 8.8 & 134 & $6.59 \%$ & 2.6 & 60 & $4.41 \%$ \\
\hline 11 & Construction College & 19.1 & 127 & $15.06 \%$ & 4.9 & 57 & $8.65 \%$ \\
\hline 12 & Jinan Baosheng site & 24.6 & 202 & $12.20 \%$ & 6.2 & 79 & $7.81 \%$ \\
\hline 13 & Quancheng Square & 30.6 & 131 & $23.33 \%$ & 7.7 & 63 & $12.22 \%$ \\
\hline 14 & Lanxiang Vocational School & 18.3 & 151 & $12.11 \%$ & 4.8 & 77 & $6.28 \%$ \\
\hline \multirow[t]{2}{*}{15} & Shandong Luneng site & 14.7 & 122 & $12.05 \%$ & 4.0 & 56 & $7.21 \%$ \\
\hline & rage of the 15 sites & 19.8 & 134.8 & $14.89 \%$ & 5.2 & 64.5 & $8.14 \%$ \\
\hline
\end{tabular}

\subsection{Scenario 2 analysis}

Table 4 lists the concentrations of $\mathrm{PM}_{10}$ and $\mathrm{PM}_{2.5}$ at each sensitive point under this scenario and their contributions to the environmental concentrations at the monitoring points. Figures 6 and 7 display the distributions of the average concentration of $\mathrm{PM}_{10}$ and $\mathrm{PM}_{2.5}$, respectively, under this scenario.

In the yellow alert scenario, dust emission had the greatest impact on the average concentration of $\mathrm{PM}_{10}$ at Kegansuo station, reaching $35.7 \mu \mathrm{g} / \mathrm{m}^{3}$. Its impact on the average
$\mathrm{PM}_{10}$ concentration across all 15 monitoring stations was $17.1 \mu \mathrm{g} / \mathrm{m}^{3}$, accounting for $13.1 \%$ of the average observed value. Dust emission had the greatest impact on the average concentration of $\mathrm{PM}_{2.5}$ at Kegansuo station, reaching $9.6 \mathrm{\mu g} / \mathrm{m}^{3}$. Its impact on the average $\mathrm{PM}_{10}$ concentration across all 15 monitoring stations was 5.1 $\mu \mathrm{g} / \mathrm{m}^{3}$, accounting for $8.2 \%$ of the average observed value. The simulation results revealed that when extremely adverse meteorological conditions occur, dust continues to have a substantial impact on air quality at the monitoring stations, despite a $35 \%$ reduction in emissions. Compared 
with the baseline scenario, the average concentrations of $\mathrm{PM}_{10}$ and $\mathrm{PM}_{2.5}$ across the 15 stations decreased by $13.6 \%$ and $1.9 \%$, respectively.

2017

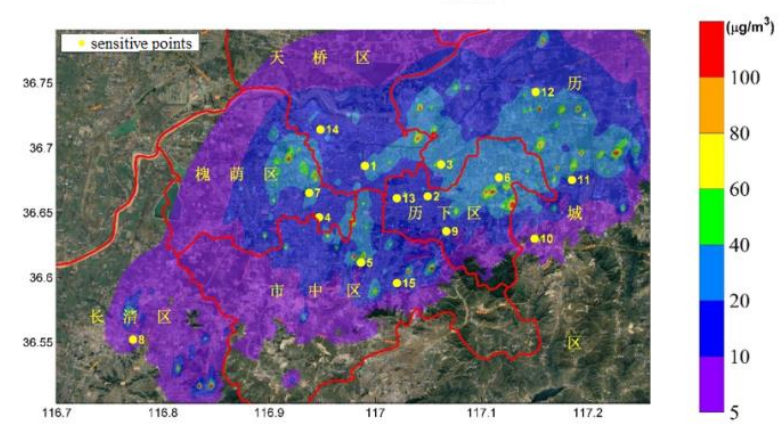

Figure 4. Average concentration of $\mathrm{PM}_{10}$ under scenario 1.

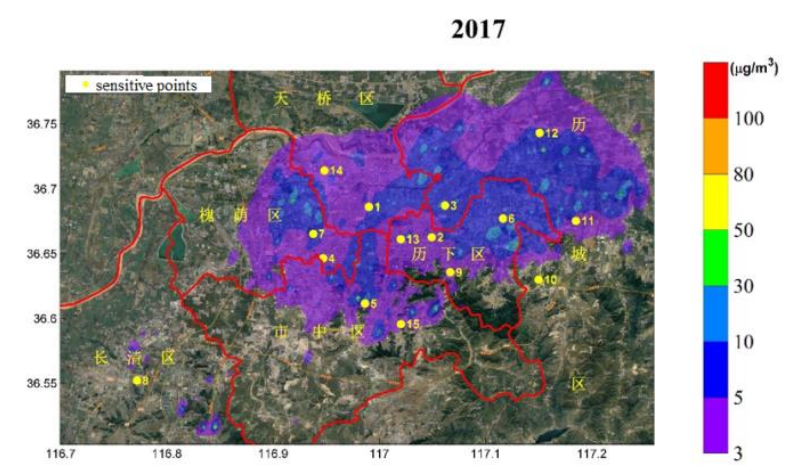

Figure 5. Average concentration of $\mathrm{PM}_{2.5}$ under scenario 1.

\subsection{Scenario 3 analysis}

Table 5 lists the concentrations of $\mathrm{PM}_{10}$ and $\mathrm{PM}_{2.5}$ at each sensitive point under this scenario and their contributions to the environmental concentrations at the monitoring points. Figures 8 and 9 display the average concentration distributions of $\mathrm{PM}_{10}$ and $\mathrm{PM}_{2.5}$, respectively, under this scenario.

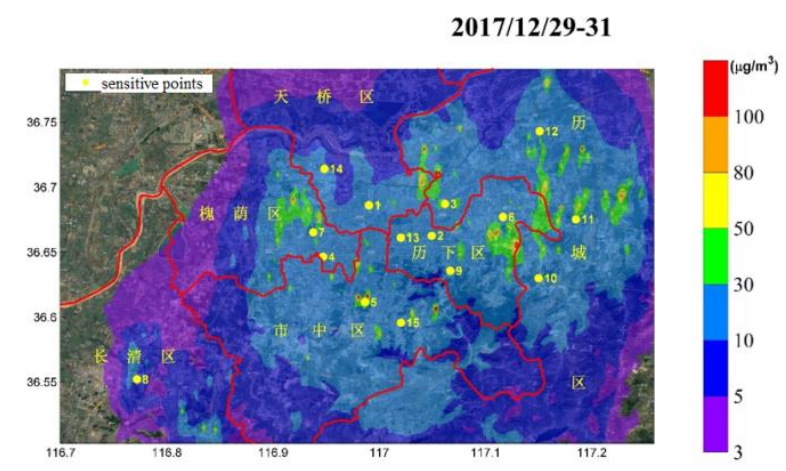

Figure 6. Average concentration of $\mathrm{PM}_{10}$ under scenario 2.

Under orange alert conditions, dust emission had the greatest impact on the average $\mathrm{PM}_{10}$ concentration at Kegansuo station, reaching $16.5 \mu \mathrm{g} / \mathrm{m}^{3}$, and its impact on the average $\mathrm{PM}_{10}$ concentration across all 15 monitoring stations was $7.9 \mu \mathrm{g} / \mathrm{m}^{3}$, accounting for $6.02 \%$ of the average monitoring value. Dust emission had the greatest impact on the average $\mathrm{PM}_{2.5}$ concentration at Kegansuo station, reaching $4.5 \mu \mathrm{g} / \mathrm{m}^{3}$, and its impact on the average
$\mathrm{PM}_{2.5}$ concentration across all 15 monitoring stations was $2.4 \mathrm{\mu g} / \mathrm{m}^{3}$, accounting for $3.77 \%$ of the average monitoring value. Spatially, the area influenced by the diffusion trajectories of $\mathrm{PM}_{10}$ and $\mathrm{PM}_{2.5}$, based on their average concentrations, was reduced. However, under adverse weather conditions, impacts on air quality at the monitoring stations were still observed. Compared with the baseline scenario, the average concentrations of $\mathrm{PM}_{10}$ and $\mathrm{PM}_{2.5}$ at the 15 stations were reduced by $60.1 \%$ and $53.8 \%$, respectively.

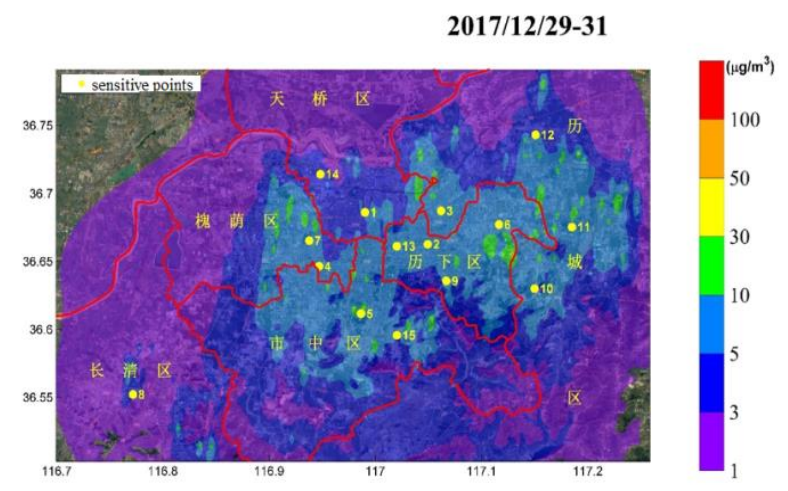

Figure 7. Average concentration of $\mathrm{PM}_{2.5}$ under scenario 2.

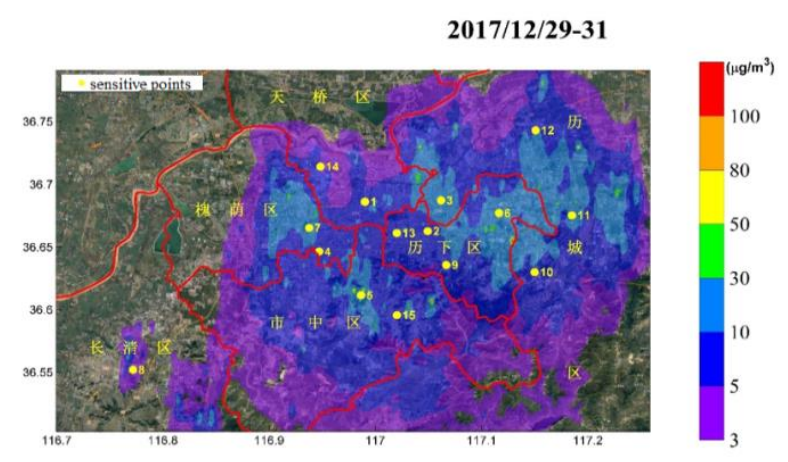

Figure 8. Average concentration of $\mathrm{PM}_{10}$ under scenario 3.

2017/12/29-31

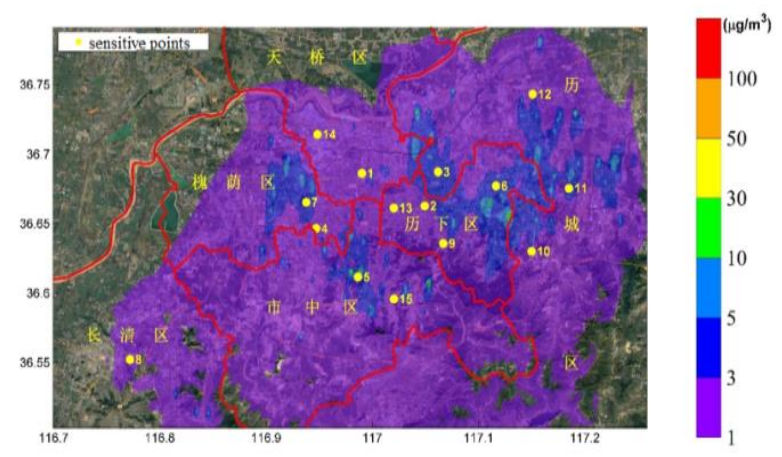

Figure 9. Average concentration of $\mathrm{PM}_{2.5}$ under scenario 3.

\subsection{Scenario 4 analysis}

Table 6 lists the concentrations of $\mathrm{PM}_{10}$ and $\mathrm{PM}_{2.5}$ at each sensitive point under this scenario and their contributions to the environmental concentrations at the monitoring points. Figures 10 and 11 display the average concentration distributions of $\mathrm{PM}_{10}$ and $\mathrm{PM}_{2.5}$, respectively, under this scenario. 


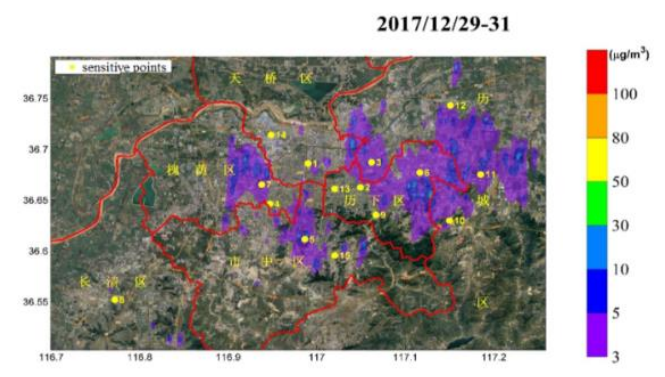

Figure 10. Average concentration of $\mathrm{PM}_{10}$ under scenario 4. 2017/12/29-31

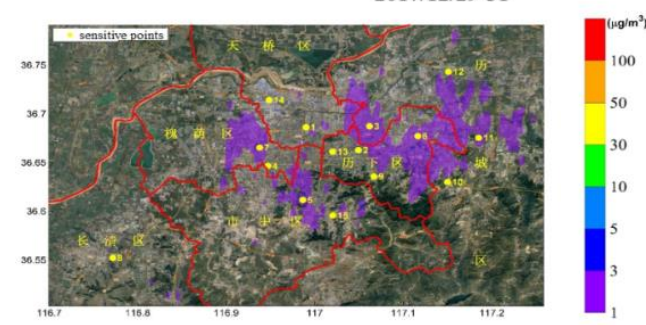

Under red alert conditions, the impact of dust emission on the average $\mathrm{PM}_{10}$ concentration at the Kegansuo station was greatest, at $5.5 \mu \mathrm{g} / \mathrm{m}^{3}$, and its impact on the average $\mathrm{PM}_{10}$ concentration across all 15 monitoring stations was $2.6 \mu \mathrm{g} / \mathrm{m}^{3}$, accounting for $2.0 \%$ of the average monitoring value. Dust emission had the greatest impact on the average $\mathrm{PM}_{2.5}$ concentration at the Kegansuo station, reaching $1.5 \mathrm{\mu g} / \mathrm{m}^{3}$. Its impact on the average $\mathrm{PM}_{2.5}$ concentration across all 15 monitoring stations was 0.8 $\mathrm{\mu g} / \mathrm{m}^{3}$, accounting for $1.26 \%$ of the average monitoring value. In terms of the spatial distributions of pollutants, Licheng District had the highest $\mathrm{PM}_{10}$ and $\mathrm{PM}_{2.5}$ concentrations. Additionally, the region of influence was significantly smaller than those in other alert scenarios and the baseline scenario. These results show that when red alert measures are adopted during the hot season, dust pollution at construction sites in Jinan is generally controlled. Compared with the baseline scenario, the average concentrations of $\mathrm{PM}_{10}$ and $\mathrm{PM}_{2.5}$ across all 15 stations decreased by $86.9 \%$ and $84.6 \%$, respectively.

Figure 11. Average concentration of PM2.5 under scenario 4.

Table 4. Concentrations of $\mathrm{PM}_{10}$ and $\mathrm{PM}_{2.5}$ under scenario 2 and their ratios to monitoring data

\begin{tabular}{|c|c|c|c|c|c|c|c|}
\hline \multirow[b]{2}{*}{ No. } & \multirow[b]{2}{*}{ Name } & \multicolumn{3}{|c|}{$\mathrm{PM}_{10}$ concentration $\left(\mu \mathrm{g} / \mathrm{m}^{3}\right)$} & \multicolumn{3}{|c|}{$\mathrm{PM}_{2.5}$ concentration $\left(\mu \mathrm{g} / \mathrm{m}^{3}\right)$} \\
\hline & & $\begin{array}{l}\text { Simulated } \\
\text { mean value }\end{array}$ & $\begin{array}{c}\text { Monitored } \\
\text { annual value }\end{array}$ & Ratio & $\begin{array}{c}\text { Simulated } \\
\text { mean value }\end{array}$ & $\begin{array}{c}\text { Monitored } \\
\text { annual value }\end{array}$ & Ratio \\
\hline 1 & Jinan chemical plant & 10.3 & 124 & $8.35 \%$ & 3.5 & 59 & $6.02 \%$ \\
\hline 2 & Air quality monitoring station & 14.0 & 132 & $10.57 \%$ & 4.7 & 70 & $6.74 \%$ \\
\hline 3 & Seed warehouse & 17.7 & 133 & $13.31 \%$ & 5.3 & 68 & $7.83 \%$ \\
\hline 4 & Second machine tool plant & 12.3 & 145 & $8.45 \%$ & 4.2 & 76 & $5.51 \%$ \\
\hline 5 & Kegansuo site & 35.7 & 121 & $29.53 \%$ & 9.6 & 59 & $16.35 \%$ \\
\hline 6 & Development zone & 20.5 & 116 & $17.70 \%$ & 5.8 & 58 & $10.02 \%$ \\
\hline 7 & Nongkesuo site & 18.5 & 148 & $12.52 \%$ & 5.4 & 62 & $8.65 \%$ \\
\hline 8 & Changing Party School & 6.3 & 122 & $5.14 \%$ & 2.3 & 64 & $3.56 \%$ \\
\hline 9 & School of Economics & 14.1 & 114 & $12.33 \%$ & 4.9 & 60 & $8.14 \%$ \\
\hline 10 & High and New School & 16.8 & 134 & $12.52 \%$ & 5.4 & 60 & $9.04 \%$ \\
\hline 11 & Construction College & 25.2 & 127 & $19.88 \%$ & 6.6 & 57 & $11.50 \%$ \\
\hline 12 & Jinan Baosheng site & 14.5 & 202 & $7.19 \%$ & 3.8 & 79 & $4.79 \%$ \\
\hline 13 & Quancheng Square & 31.1 & 131 & $23.77 \%$ & 8.4 & 63 & $13.28 \%$ \\
\hline 14 & Lanxiang Vocational School & 7.9 & 151 & $5.23 \%$ & 2.6 & 77 & $3.43 \%$ \\
\hline 15 & Shandong Luneng site & 11.4 & 122 & $9.31 \%$ & 4.4 & 56 & $7.79 \%$ \\
\hline & Average of the 15 sites & 17.1 & 134.8 & $13.05 \%$ & 5.1 & 64.5 & $8.18 \%$ \\
\hline
\end{tabular}

Table 5. Concentrations of $\mathrm{PM}_{10}$ and $\mathrm{PM}_{2.5}$ under scenario 3 and their ratios to monitoring data

\begin{tabular}{|c|c|c|c|c|c|c|c|}
\hline \multirow[b]{2}{*}{ No. } & \multirow[b]{2}{*}{ Name } & \multicolumn{3}{|c|}{$\mathrm{PM}_{10}$ concentration $\left(\mu \mathrm{g} / \mathrm{m}^{3}\right)$} & \multicolumn{3}{|c|}{$\mathrm{PM}_{2.5}$ concentration $\left(\mu \mathrm{g} / \mathrm{m}^{3}\right)$} \\
\hline & & $\begin{array}{c}\text { Simulated } \\
\text { mean value }\end{array}$ & $\begin{array}{c}\text { Monitored } \\
\text { annual value }\end{array}$ & Ratio & $\begin{array}{c}\text { Simulated } \\
\text { mean value }\end{array}$ & $\begin{array}{c}\text { Monitored } \\
\text { annual value }\end{array}$ & Ratio \\
\hline 1 & Jinan chemical plant & 4.8 & 124 & $3.85 \%$ & 1.6 & 59 & $2.78 \%$ \\
\hline 2 & Air quality monitoring station & 6.4 & 132 & $4.88 \%$ & 2.2 & 70 & $3.11 \%$ \\
\hline 3 & Seed warehouse & 8.2 & 133 & $6.15 \%$ & 2.5 & 68 & $3.61 \%$ \\
\hline 4 & Second machine tool plant & 5.7 & 145 & $3.90 \%$ & 1.9 & 76 & $2.54 \%$ \\
\hline 5 & Kegansuo site & 16.5 & 121 & $13.63 \%$ & 4.5 & 59 & $7.55 \%$ \\
\hline 6 & Development zone & 9.5 & 116 & $8.17 \%$ & 2.7 & 58 & $4.63 \%$ \\
\hline 7 & Nongkesuo site & 8.5 & 148 & $5.77 \%$ & 2.5 & 62 & $3.99 \%$ \\
\hline 8 & Changing Party School & 2.9 & 122 & $2.37 \%$ & 1.1 & 64 & $1.64 \%$ \\
\hline 9 & School of Economics & 6.5 & 114 & $5.69 \%$ & 2.3 & 60 & $3.76 \%$ \\
\hline 10 & High and New School & 7.7 & 134 & $5.78 \%$ & 2.5 & 60 & $4.17 \%$ \\
\hline 11 & Construction College & 11.7 & 127 & $9.18 \%$ & 3.0 & 57 & $5.31 \%$ \\
\hline 12 & Jinan Baosheng site & 6.7 & 202 & $3.32 \%$ & 1.7 & 79 & $2.21 \%$ \\
\hline 13 & Quancheng Square & 14.4 & 131 & $10.97 \%$ & 3.9 & 63 & $6.13 \%$ \\
\hline 14 & Lanxiang Vocational School & 3.6 & 151 & $2.41 \%$ & 1.2 & 77 & $1.58 \%$ \\
\hline 15 & Shandong Luneng site & 5.2 & 122 & $4.30 \%$ & 2.0 & 56 & $3.60 \%$ \\
\hline & Average of the 15 sites & 7.9 & 134.8 & $6.02 \%$ & 2.4 & 64.5 & $3.77 \%$ \\
\hline
\end{tabular}


Table 6 Concentrations of $\mathrm{PM}_{10}$ and $\mathrm{PM}_{2.5}$ under scenario 4 and their ratios to monitoring data

\begin{tabular}{|c|c|c|c|c|c|c|c|}
\hline \multirow[b]{2}{*}{ No. } & \multirow[b]{2}{*}{ Name } & \multicolumn{3}{|c|}{$\mathrm{PM}_{10}$ concentration $\left(\mu \mathrm{g} / \mathrm{m}^{3}\right)$} & \multicolumn{3}{|c|}{$\mathrm{PM}_{2.5}$ concentration $\left(\mu \mathrm{g} / \mathrm{m}^{3}\right)$} \\
\hline & & $\begin{array}{l}\text { Simulated } \\
\text { mean value }\end{array}$ & $\begin{array}{c}\text { Monitored } \\
\text { annual value }\end{array}$ & Ratio & $\begin{array}{l}\text { Simulated } \\
\text { mean value }\end{array}$ & $\begin{array}{c}\text { Monitored } \\
\text { annual value }\end{array}$ & Ratio \\
\hline 1 & Jinan chemical plant & 1.6 & 124 & $1.28 \%$ & 0.5 & 59 & $0.93 \%$ \\
\hline 2 & Air quality monitoring station & 2.1 & 132 & $1.63 \%$ & 0.7 & 70 & $1.04 \%$ \\
\hline 3 & Seed warehouse & 2.7 & 133 & $2.05 \%$ & 0.8 & 68 & $1.20 \%$ \\
\hline 4 & Second machine tool plant & 1.9 & 145 & $1.30 \%$ & 0.6 & 76 & $0.85 \%$ \\
\hline 5 & Kegansuo site & 5.5 & 121 & $4.54 \%$ & 1.5 & 59 & $2.51 \%$ \\
\hline 6 & Development zone & 3.2 & 116 & $2.72 \%$ & 0.9 & 58 & $1.54 \%$ \\
\hline 7 & Nongkesuo site & 2.8 & 148 & $1.92 \%$ & 0.8 & 62 & $1.33 \%$ \\
\hline 8 & Changing Party School & 1.0 & 122 & $0.79 \%$ & 0.4 & 64 & $0.55 \%$ \\
\hline 9 & School of Economics & 2.2 & 114 & $1.90 \%$ & 0.8 & 60 & $1.25 \%$ \\
\hline 10 & High and New School & 2.6 & 134 & $1.93 \%$ & 0.8 & 60 & $1.39 \%$ \\
\hline 11 & Construction College & 3.9 & 127 & $3.06 \%$ & 1.0 & 57 & $1.77 \%$ \\
\hline 12 & Jinan Baosheng site & 2.2 & 202 & $1.11 \%$ & 0.6 & 79 & $0.74 \%$ \\
\hline 13 & Quancheng Square & 4.8 & 131 & $3.65 \%$ & 1.3 & 63 & $2.04 \%$ \\
\hline 14 & Lanxiang Vocational School & 1.2 & 151 & $0.80 \%$ & 0.4 & 77 & $0.53 \%$ \\
\hline \multirow[t]{2}{*}{15} & Shandong Luneng site & 1.7 & 122 & $1.43 \%$ & 0.7 & 56 & $1.20 \%$ \\
\hline & Average of the 15 sites & 2.6 & 134.8 & $2.01 \%$ & 0.8 & 64.5 & $1.26 \%$ \\
\hline
\end{tabular}

Table 7. Concentrations of $\mathrm{PM}_{10}$ and $\mathrm{PM}_{2.5}$ under scenario 5 and their ratios to monitoring data

\begin{tabular}{|c|c|c|c|c|c|c|c|}
\hline \multirow[b]{2}{*}{ No. } & \multirow[b]{2}{*}{ Name } & \multicolumn{3}{|c|}{$\mathrm{PM}_{10}$ concentration $\left(\mu \mathrm{g} / \mathrm{m}^{3}\right)$} & \multicolumn{3}{|c|}{$\mathrm{PM}_{2.5}$ concentration $\left(\mu \mathrm{g} / \mathrm{m}^{3}\right)$} \\
\hline & & $\begin{array}{l}\text { Simulated } \\
\text { mean value }\end{array}$ & $\begin{array}{c}\text { Monitored } \\
\text { annual value }\end{array}$ & Ratio & $\begin{array}{l}\text { Simulated } \\
\text { mean value }\end{array}$ & $\begin{array}{c}\text { Monitored } \\
\text { annual } \\
\text { value }\end{array}$ & Ratio \\
\hline 1 & Jinan chemical plant & 11.9 & 124 & $9.56 \%$ & 3.3 & 59 & $5.55 \%$ \\
\hline 2 & Air quality monitoring station & 10.6 & 132 & $8.00 \%$ & 3.0 & 70 & $4.32 \%$ \\
\hline 3 & Seed warehouse & 13.2 & 133 & $9.96 \%$ & 3.6 & 68 & $5.36 \%$ \\
\hline 4 & Second machine tool plant & 10.0 & 145 & $6.91 \%$ & 2.8 & 76 & $3.69 \%$ \\
\hline 5 & Kegansuo site & 10.3 & 121 & $8.51 \%$ & 2.9 & 59 & $4.86 \%$ \\
\hline 6 & Development zone & 16.8 & 116 & $14.45 \%$ & 4.4 & 58 & $7.55 \%$ \\
\hline 7 & Nongkesuo site & 10.7 & 148 & $7.22 \%$ & 2.9 & 62 & $4.73 \%$ \\
\hline 8 & Changing Party School & 4.1 & 122 & $3.38 \%$ & 1.2 & 64 & $1.87 \%$ \\
\hline 9 & School of Economics & 9.8 & 114 & $8.62 \%$ & 2.8 & 60 & $4.66 \%$ \\
\hline 10 & High and New School & 6.8 & 134 & $5.10 \%$ & 2.0 & 60 & $3.38 \%$ \\
\hline 11 & Construction College & 12.5 & 127 & $9.84 \%$ & 3.3 & 57 & $5.78 \%$ \\
\hline 12 & Jinan Baosheng site & 13.8 & 202 & $6.83 \%$ & 3.6 & 79 & $4.55 \%$ \\
\hline 13 & Quancheng Square & 12.0 & 131 & $9.15 \%$ & 3.3 & 63 & $5.28 \%$ \\
\hline 14 & Lanxiang Vocational School & 11.1 & 151 & $7.36 \%$ & 3.0 & 77 & $3.94 \%$ \\
\hline \multirow[t]{2}{*}{15} & Shandong Luneng site & 8.4 & 122 & $6.88 \%$ & 2.4 & 56 & $4.28 \%$ \\
\hline & Average of the 15 sites & 10.8 & 134.8 & $8.12 \%$ & 3.0 & 64.5 & $4.65 \%$ \\
\hline
\end{tabular}

\subsection{Scenario 5 analysis}

Table 7 lists the $\mathrm{PM}_{10}$ and $\mathrm{PM}_{2.5}$ concentrations at each sensitive point under this scenario and their contributions to the environmental concentrations at the monitoring points. Figures 12 and 13 show the average concentration distributions of $\mathrm{PM}_{10}$ and $\mathrm{PM}_{2.5}$, respectively, under this scenario.

When all construction sites were shut down within a 2-km radius of the monitoring point, dust emission had the greatest impact on the average $\mathrm{PM}_{10}$ concentration at stations within the development zone, reaching 16.7 $\mu \mathrm{g} / \mathrm{m}^{3}$. Its impact on the average $\mathrm{PM}_{10}$ concentration across all 15 monitoring stations was $10.8 \mu \mathrm{g} / \mathrm{m}^{3}$, accounting for $8.12 \%$ of the average monitoring value. Dust emission had the greatest impact on the average $\mathrm{PM}_{2.5}$ concentration at stations within the development zone, reaching $4.3 \mu \mathrm{g} / \mathrm{m}^{3}$. Its impact on the average $\mathrm{PM}_{2.5}$ concentration of the 15 monitoring stations was $3.0 \mu \mathrm{g} / \mathrm{m}^{3}$, accounting for $4.65 \%$ of the average monitoring value. Compared with the baseline scenario, the average concentrations of $\mathrm{PM}_{10}$ and $\mathrm{PM}_{2.5}$ across the 15 stations under this scenario decreased by $45.5 \%$ and $42.3 \%$, 
respectively. Spatially, the diffusion trajectories of $\mathrm{PM}_{10}$ and $\mathrm{PM}_{2.5}$ were concentrated in Lixia, Huaiyin, the northern part of Shizhong District, the southern part of Tianqiao, and the western part of Licheng. The results of this study demonstrated that shutting down construction sites within $2 \mathrm{~km}$ of the sensitive points during the hot season significantly reduced particulate matter concentrations at individual monitoring stations, although short-term concentration peaks occurred. Compared with the baseline scenario, the average $\mathrm{PM}_{10}$ and $\mathrm{PM}_{2.5}$ concentrations at the 15 stations were reduced by $45.5 \%$ and $42.3 \%$, respectively.

\section{7}

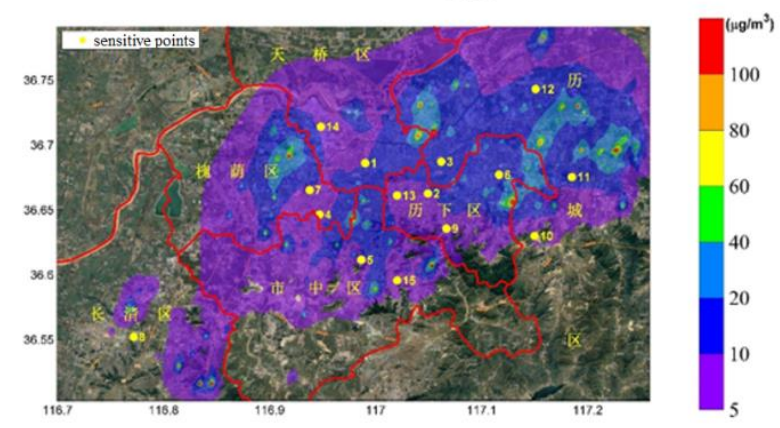

Figure 12. Average concentration of $\mathrm{PM}_{10}$ under scenario 5.

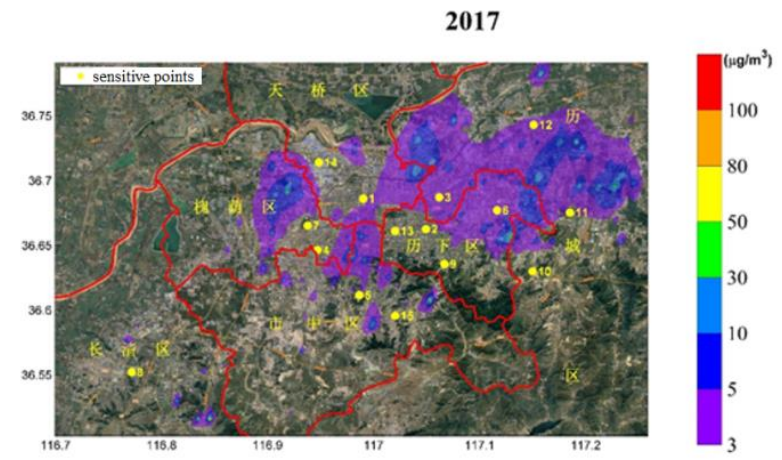

Figure 13. Average concentration of $\mathrm{PM}_{2.5}$ under scenario 5.

\section{Conclusions and recommendations}

Dust emission from construction sites has a significant impact on air quality in Jinan. The impacts of dust emission on the average concentrations of $\mathrm{PM}_{10}$ and $\mathrm{PM}_{2.5}$ were 19.8 and $5.2 \mu \mathrm{g} / \mathrm{m}^{3}$, respectively. Dust emission had the greatest impact on the stations of Quancheng Square, Kegansuo and within the development zone. Under adverse weather conditions, high-level alert measures are required to reduce the impact of construction site emissions on environmental quality. Considering the economic and social effects of emission reduction, when temporary control measures are required, shutting down construction sites within a $2-\mathrm{km}$ radius of monitoring stations is a feasible plan that aligns with the requirements of integrated environmental management.

\section{Acknowledgments}

This work was funded by the National Key Research and Development Program of China (No. 2016YFC0204100) and the National Natural Science Foundation of China (No. 41705112).

\section{References}

Anqi L., Xiaoyang C., Yiming L., et al. (2017). A numerical simulation of $\mathrm{PM}_{2.5}$ and $\mathrm{O}_{3}$ composite pollution process of in the Pearl River Delta. China Environmental Science, 37(11), 4022-4031. (In Chinese).

Atabi F., Jafarigol F., Moattar F., et al. (2016). Comparison of AERMOD and CALPUFF models for simulating $\mathrm{SO}_{2}$ concentrations in a gas refinery. Environmental Monitoring and Assessment, 188(9):516.1-516.13.

Chang Y., Wang J., Zhu Z., et al. (2020). A salient oceanic driver for the interannual variability of wintertime haze days over the Pearl River Delta region, China. Theoretical and Applied Climatology. (in Chinese)

Chung Y.S., Kim H.S. and Chun Y. (2014). On large-scale transport of dust storms and anthropogenic dust-falls over East Asia observed in Central Korea in 2009. Asia Pacific Journal of Atmospheric Sciences, 50(3), 345-354.

Don N.C., Araki H., Hang N.T.M., et al. (2008). Modeling groundwater flow and its associated environmental problem in a lowland coastal plain: a first step towards a sustainable development plan. Environment Development \& Sustainability, 10(2), 219-231.

Junpen A., Garivait S. and Bonnet S. (2013). Estimating emissions from forest fires in Thailand using MODIS active fire product and country specific data. Asia Pacific Journal of Atmospheric Sciences, 49(3), : 389-400.

Kirthiga S.M. and Patel N.R. (2018). Impact of updating land surface data on micrometeorological weather simulations from the WRF model. Atmósfera, 31(2), 165-183.

Latinopoulos D., Konstantinou Z. and Krestenitis Y. (2012). Simulation and multicriteria analysis in sustainable coastal planning: the case of aquaculture in Thermaikos Gulf, Greece. Environment Development \& Sustainability, 14(6), 10271045.

Liu Z., Dong Z., Zhang Z., et al. (2019). Spatial and temporal variation of the near-surface wind regimes in the Taklimakan Desert, Northwest China. Theoretical and Applied Climatology, 138, 433-447. (In Chinese).

Maity S., Mandal M., Nayak S., et al. (2017). Performance of cumulus parameterization schemes in the simulation of Indian Summer Monsoon using RegCM4. Atmósfera, 30(4), 287-309.

Misra A.K., Lata K. and Shukla J.B. (2014). Effects of population and population pressure on forest resources and their conservation: a modeling study. Environment Development \& Sustainability, 16(2), 361-374.

Niu S.J. and Zhang Q.Y. (2010). Scattering and absorption coefficients of aerosols in a semi-arid area in China: Diurnal cycle, seasonal variability and dust events. Asia Pacific Journal of Atmospheric Sciences, 46(1), 65-71.

Pusheng Z., Yinchang F., Yufen Z., et al. (2009). Research and application of a quantitative model for emission factors of construction dust. China Environmental Science, 29(6), 567573. (In Chinese).

Shan L., Qingyan F., Qizhen L., et al. (2018). Characteristics of dust pollution in the structural construction stage of typical construction sites of Shanghai in autumn. Environmental Pollution \& Control, 40(12), 1394-1399. (In Chinese).

Shekarrizfard M., Faghih-Imani A., Tetreault L.F., et al. (2017). Modelling the spatio-temporal distribution of ambient nitrogen dioxide and investigating the effects of public transit policies on population exposure. Environmental Modelling \& Software, 91(MAY), 186-198.

Wenting Z., Xuesong W., Zhaorong L., et al. (2010). Construction fugitive $\mathrm{PM}_{10}$ emission and its influences on air quality in 
Guiyang. Acta Scientiarum Naturalium Universitatis Pekinensis, 46(2), 258-264. (In Chinese).

Won H.Y., Kim Y.-H. and Lee H.-S. (2009). An application of brightness temperature received from a ground-based microwave radiometer to estimation of precipitation occurrences and rainfall intensity. Asia-Pacific Journal of the Atmospheric Sciences, 45(1), 55-69.

Yang R. and Cui B. (2012). Framework of integrated stormwater management of Jinan City, China. Procedia Environmental Sciences, 13, 2346-2352.

Yifeng X., Zhen Z., Yuhu H., et al. (2017). Fugitive dust emission characteristics from building construction sites of Beijing. Environmental Science, 38(6),: 2231-2237. (In Chinese).

Zhang Q., Streets D.G., Carmichael G.R et al. (2009). Asian emissions in 2006 for the NASA INTEX-B mission. Atmospheric Chemistry and Physics Atmos, 9, 5131-5153. 